\title{
AN UNDESIRABLE IMMIGRANT
}

\author{
By ARCHIE BUDD \\ Swift Current
}

Several times recently there have been sent in for identification plants of Black Henbane (Hyoscyamus niger L.) sometimes called Foetid Nightshade or Poison Tobacco. This is an annual or a biennial weed, introduced from Europe and western Asia, and found in waste places and odd corners of gardens, etc. It seems to favour no particular district and has been found at points scattered right across the country.

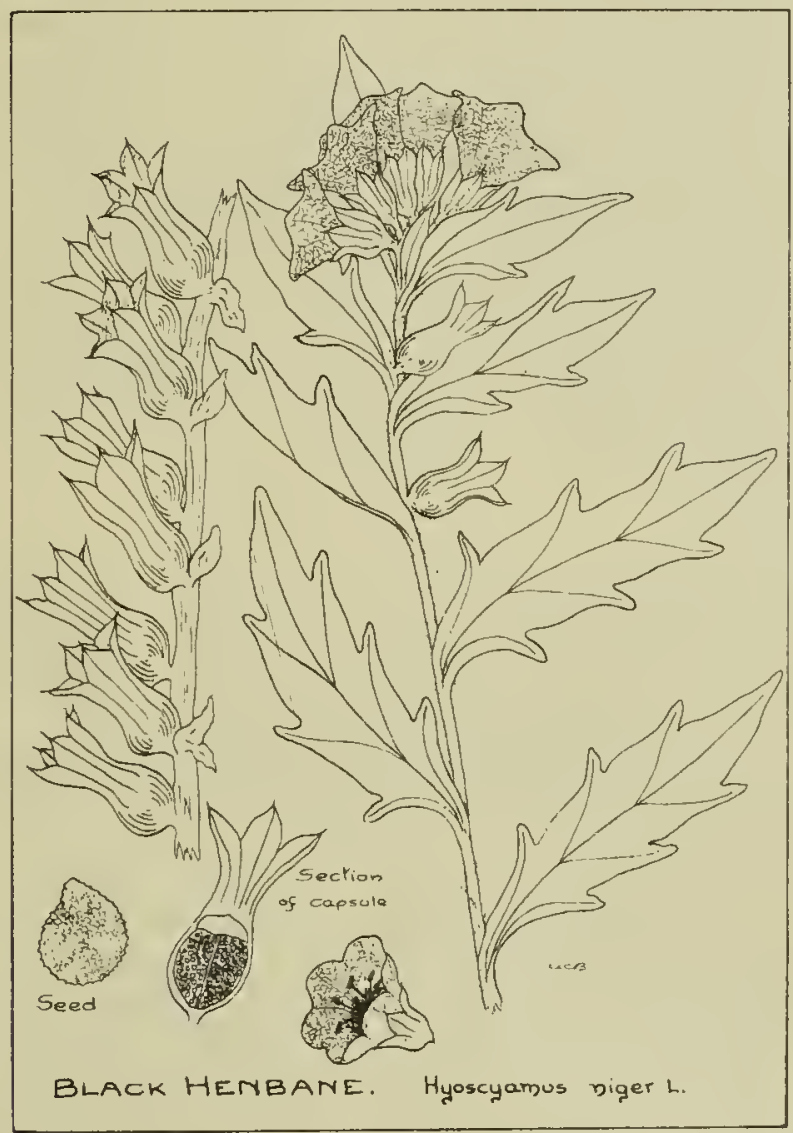

Black Henbane grows from one to two feet in height from a large, thick root and bears alternate leaves from 2 to 9 inches long, generally coarsely toothed and clasping the stem. The whole plant is sticky, hairy and foul smelling, and all portions are very poisonous. The flowers are about an inch or more across, funnel-form with five lobes and are of a greenish yellow colour with very conspicuous, fine purple veins. They are borne on one side of the stem in a leafy, terminal spike and later form very easily recognized fruiting capsules about a half inch long and enclosed in a prominent parchmenty, swollen calyx. The top of the capsule falls off like a lid to release the numerous seeds, which are slaty in colour, flattened and covered with minute depressions. The capsule has a central partition dividing it into two compartments.

All parts of the plant are poisonous, from the roots to the seeds. Serious results have been caused by using the roots in mistake for parsnips or chicory, and by using the young shoots as a vegetable. The seeds are particularly dangerous, twenty of them being claimed to be sufficient to cause serious sickness in adults, and death to hens and smaller creatures.

The scientific name Hyoscyamus means "hog bean" and the plant is a member of the Solanaceae or Potato Family, practically all members of which are poisonous to some degree. Potato apples (the fruit of the potato), green tubers and leaves are poisonous, tomato foiliage should not be eaten, and thornapple (Datura), Bitter-sweet, and other poisonous plants belong to this family, as do Petunias, Schizanthus, Salpiglossis, Nierembergias of our gardens and also Tobacco which many call a poisonous weed.

\section{Ducks in Formation}

MRS. N. KEYTE, Pollockville, Alta.

We have never had so many birds or so many wild flowers as this year. My husband is no hunter and our ranch is almost a sanctuary. Three weeks ago we came to a big slough and ranged along the north and east sides were three rows of ducks, drawn up in formation. As far as we could estimate there were between two and three hundred of them. The noisy little "cow punching" touch scared them, but we had never seen them like that before.

We also have quite a few Prairie Chicken now, though several years ago they were reduced to one or two. They always stay more or less in the same two areas, though in winter they will come around the stacks and buildings in bad weather. 